\title{
Analysis of Productive Resources of Maize Crop Among Farming Households in Ekiti State, Nigeria
}

\author{
Owoeye R. S. ", Adetule F. S., Ajayi G. T. \\ Department of Agricultural Economics and Extension Services, Ekiti State University, Ado - Ekiti, Nigeria \\ Email address: \\ donetal13@yahoo.com (Owoeye R. S.), rufus.owoeye@eksu.edu.ng (Owoeye R. S.) \\ ${ }^{*}$ Corresponding author
}

\section{To cite this article:}

Owoeye R. S., Adetule F. S., Ajayi G. T. Analysis of Productive Resources of Maize Crop Among Farming Households in Ekiti State, Nigeria. International Journal of Agricultural Economics. Vol. 2, No. 5, 2017, pp. 142-148. doi: 10.11648/j.ijae.20170205.11

Received: June 28, 2017; Accepted: July 7, 2017; Published: August 15, 2017

\begin{abstract}
This study examined productive resources of maize crop among farming households in Ekiti State, Nigeria. The study used multistage sampling techniques. Data were collected from 120 maize farmers through well-structured questionnaires from three Local Government Areas of Ekiti State. The collected data were analyzed by using descriptive statistics, and stochastic frontier regression model. Results from descriptive analysis showed that 30 percent of the maize farmers had secondary school education and above. Majority of the respondents $(66.70 \%)$ had between 5 and 8 members that made up the household in the study area. It was revealed through the study that the majority of the respondents produced on a fairly large scale with average maize farm size of 3.39 hectares. Also, $80.0 \%$ of the maize farmers in the study area had more than 15 years farming experience. With profit of 116,590 per hectare and percentage profit of $58.63 \%$, the venture is considered to be highly profitable. Farmers who invested 1 realized revenue of 1.59 . The level of technical efficiency in maize production in Ekiti State ranged from $29.8 \%$ to $96.5 \%$ with a mean of $64.3 \%$. This means that there are substantial opportunities to increase productivity and income through more efficient utilization of productive resources The RTS parameter (0.931) was obtained from the summation of the coefficients of the estimated inputs (elasticities) which indicates that maize production in the study area was in the Stage II of the production surface. Depreciation, hired labour, family labour, farm size and quantity of seed are the major farm specific variables that influence efficiency of the maize farmers while farming experience, extension access, land acquisition and access to credit contributed to technical inefficiency. It is therefore suggested that effort should be geared towards increasing the technical manpower of farmers, land redistribution policy that will increase the farm size of farmers in order to boost maize production should be encouraged; and in order to increase farmers' profit, variable costs have to be cut down, since the bulk of the variable cost is incurred on labour, which would lead to greater gross margins and hence the profitability of the enterprise.
\end{abstract}

Keywords: Productive Resources, Maize Crop, Budgetary Analysis, Technical Efficiency

\section{Introduction}

Agriculture belongs to the real sector of Nigerian economy. It is characterized by a multitude of small scale farmers scattered over wide expanse of land area, with small holding ranging from 0.05 to 3.0 hectares per farm land, rudimentary farm systems, low capitalization and low yield per hectare. Agriculture provides primary means of employment for Nigerians and accounts for more than onethird of total Gross Domestic Product (GDP) and labour force $[1,2]$.

Agricultural share of the GDP stood at about $90 \%$ before independence in 1960, about 56\% between 1960-1969 and more than $40 \%$ since 1986 [3]. Agriculture is the economic engine of most economies in Sub-Saharan Africa (SSA) contributing at least 70 percent of employment, 40 percent of export earnings, and 30 percent of Gross Domestic Product (GDP) and up to 30 percent of foreign exchange earnings [4]. Efficient resource use remains a major challenge for policy and initiatives which are targeted at improving livelihoods in the region [5].

Agriculture is also of great importance to the Nigerian economy as it engages about $70 \%$ of the labour force and $40 \%$ of the Gross Domestic Product [6]. It provides food for the teeming population and raw materials for industries. 
Maize grain production in Nigeria was estimated to have doubled from seven million metric tons in 2004 to fourteen thousand metric tons in 2007 and this had enhanced income generation, wealth creation, poverty alleviation and improved food security. The inclusion of Maize in the diet of people had improved greatly human nutrition especially in Carbohydrate, Fats and some Enzymes [7]. Maize contains calcium, iron, carotene, thiamine, riboflavin and niacin among others and in addition to being a good source of energy, maize oil contains high level of natural antioxidants resulting in stable oil with good flavour [8]

To be self-sufficient in the production of food, the problem of promoting most promising crops in the country has to be tackled. Until recently, most African government including Nigeria has not helped the situation because of importation of large quantities of grains mainly to satisfy the political active urban population, thereby causing discouragement to the rural farmers producing food crop which is more adaptable to the local environment conditions. The importance of Maize had been stressed in previous research as the crop had been found to be useful for human consumption; livestock feed and industrial purposes [9].

Agriculture in Nigeria as in most other developing countries is dominated by small farm producers [10]. Smallholder farmers constitute about $80 \%$ of the farming population in Nigeria [11]. These smallholder farmers although individually look insignificant but collectively form an important foundation upon which the Nigerian agriculture rests. Several constraints and barriers, which appear insurmountable, limit the overall farming activities and if this is anything to go by, the destiny of a developing economy heavily rests on the shoulder of the small producers.

The question of how efficient smallholder farmers use farm resources are of considerable interest to agricultural economists. The farm-level efficiency of smallholder resources has important implications for the agricultural development of a nation. Efficient farmers make better use of existing resources and produce their output at the lowest cost, thus achieving the food security objective. The efficient method of producing a product is that which uses the least amount of resources to get a given amount of the product. An increase in efficiency in arable crop production could present a ray of hope and could lead to an improvement in the welfare of the farmer and consequently a reduction in their poverty level and food insecurity. Low yields are as a result of inefficient production techniques manifested in technical and allocative inefficiencies, over-reliance on household resources, labour-intensive agricultural technology and rapidly declining soil productivity [12].

Nigeria's food production in the aggregate has been growing at about $2.5 \%$ per annum while food demand has been growing at a rate of more than 3.5\% [13] and 90\% of the production rate is from rural farmers (Nwaru, 2005). These categories of farmer are bedeviled with natural hazards such as fire outbreak, flood, drought, diseases and pest attacks which often reduce agricultural productivity over the years [14].

\section{Research Method}

\subsection{Study Area}

The study was conducted in Ekiti State, Nigeria. It is entirely situated within the tropics. It is located between longitudes $40^{\circ} 51^{\prime}$ and $50^{\circ} 451^{\prime}$ East of the meridian and $70^{\circ}$ $151^{\prime}$ and $80^{\circ} 51^{\prime}$ North of the Equator. Temperature ranges between $21^{\circ}$ and $28^{\circ} \mathrm{C}$ with high humidity. Food crops like yam, cassava, and also grains like rice and maize are grown in large quantities. Other notable crops like kola nut and varieties of fruits are also cultivated in commercial quantities.

\subsection{Data Collection and Sampling Techniques}

The data, mainly from primary source, were collected from 120 maize farmers selected with the aid of a multistage sampling technique. The first stage was the purposive selection of four Local Government Areas; Ikole, Ido Osi, Ekiti West and Oye Ekiti due to the prevalence of maize production in the areas (ADP Ado Ekiti). Secondly, random sampling technique was adopted to select three towns or villages from the four Local Government Areas, making 12 towns/villages altogether. The last stage made use of random selection of thirty (30) farmers from each Local Government Areas that is, ten (10) respondents from each of the twelve towns/villages, making a total sample size of 120 respondents.

\subsection{Model Specifications}

In the analysis of the of the production efficiency of maize farmers, stochastic production frontier was employed using the variant of the stochastic production analysis adopted by [15]. Following [16], considering a farmer using inputs $X_{1}$, $\mathrm{X}_{2}, \mathrm{Xn}$ to produce output $\mathrm{Y}$, efficient transformation of inputs into output is characterized by the production function $\mathrm{f}(\mathrm{X})$, which shows the maximum output obtainable from various input vectors. The stochastic frontier production is defined as:

$$
Y i=f\left(X_{i}, \beta\right) \exp \left(V_{i}-U_{i}\right) ;=1,2 n
$$

Where,

$\mathrm{Yi}=$ production of the ith farm

$\mathrm{X}_{\mathrm{i}}=$ vector of input quantities of the ith farm

$\beta=$ vector of unknown parameters of the ith farm

$\mathrm{V}_{\mathrm{i}}=$ random error associated with random factors not under the control of the farm e.g. weather.

$U_{i}=$ inefficiency effects (one-sided error with $U_{0}$ ) i.e. $U_{i}$ are non-negative with technical inefficiency in production.

$\left(\mathrm{V}_{\mathrm{i}}-\mathrm{U}_{\mathrm{i}}\right)=$ composite error term

The random error $\left(V_{i}\right)$ is assumed to be normally distributed $\mathrm{N} \sim\left(0, \sigma_{\mathrm{v}}{ }^{2}\right)$ random variable that is Independent of $U_{i}$. Technical efficiency of an individual farmer was defined in terms of the ratio of the observed output to the corresponding frontier output, given the available technology.

A Cobb Douglas logarithm function was adopted for this study. The estimated Cobb-Douglas Stochastic frontier Production function is assumed to specify the technology of 
the farmers. Thus:

$$
\begin{aligned}
& \text { In } Y i=\beta_{0}+\beta_{1} \operatorname{In} X_{1}+\beta_{2} \operatorname{In} X_{2}+\beta_{3} \operatorname{In} X_{3}+\beta_{4} \operatorname{InX} X_{4}+\beta_{5} \operatorname{InX}_{5}+ \\
& \mathrm{V}_{\mathrm{i}}-\mathrm{U}_{\mathrm{i}}
\end{aligned}
$$

Where,

$\ln =$ Logarithm to base e

$\mathrm{X}_{\mathrm{i}}=$ Land area devoted to maize production (hectare)

$\mathrm{X}_{2}=$ Quality of seed (kilograms)

$\mathrm{X}_{2}=$ Amount of family labour (man/day)

$\mathrm{X}_{3}=$ Amount of hired labour (man day)

$\mathrm{X}_{4}=$ Value of fixed capital input used (depreciated value of farm tools \& equipment) (N)

$\mathrm{X}_{5}=$ Value of other working capital used (fertilizers, herbicides, pesticides) (N)

$\mathrm{V}_{\mathrm{i}}=$ Random error assumed to be independent of $\mathrm{Ui}$, identical and normally distributed with Zero mean and constant variance $\mathrm{N} \sim\left(0, \sigma_{\mathrm{v}}{ }^{2}\right)$.

$\mathrm{U}_{\mathrm{i}}=$ technical inefficiency effects which are assumed to be independent of $\mathrm{Vi}$.

They are non-Negative truncation at zero or half normal distribution with $\mathrm{N}\left(0, \sigma_{\mathrm{Ui}}^{2}\right)$.

$\beta_{\mathrm{i}}=$ The scalar parameters to be estimated

Technical Inefficiency Model

It was assumed that the technical inefficiency effects are independently distributed and arise by truncation (at zero) of the normal distribution with mean $\mathrm{U}_{\mathrm{i}}$ and variance $\delta_{2}$, where $\mathrm{U}_{\mathrm{i}}$ is specified as;

$\mathrm{U}_{\mathrm{i}}=\delta_{0}+\delta_{1} \mathrm{Z}_{1}+\delta_{2} \mathrm{Z}_{2}+\delta_{3} \mathrm{Z}_{3}+\delta_{4} \mathrm{Z}_{4}+\delta_{5} \mathrm{Z}_{5}+\delta_{6} \mathrm{Z}_{6}+\delta_{7} \mathrm{Z}_{7}+\delta_{\mathrm{n}} \mathrm{Z}_{\mathrm{n}}(3)$

Where, $\mathrm{Ui}=$ Technical inefficiency of the ith farmer

$Z_{1}=$ Age of the farmer in years

$Z_{2}=$ Level of education in no. of years spent in school.

$Z_{3}=$ Farming experience in years

$Z_{4}=$ Dummy variable for sex of the farmer $(1=$ female, 0 $=$ male)

$Z_{5}=$ Dummy variable for extension access $(1=$ Yes, $0=$ No)

$\mathrm{Z}_{6}=$ Dummy variables for access to credit $(1=$ Yes, $0=$ No $)$

$Z_{7}=$ Dummy variables for access to fertilizer $(1=$ Yes, $0=$ No $)$

$\mathrm{Z}_{8}=$ Land acquisition (owned, leased, borrowed, etc).

$\delta_{1}-\delta_{7}=$ unknown parameters estimated.

\section{Results and Discussions}

\subsection{Socio-Economic Characteristics of the Respondents}

The analysis of the socio-economic characteristics of the respondents is presented in Table 1 . The study revealed that male farmers dominated maize production with $76.7 \%$ of them actively involved with majority of them married and relatively old people with about 78.7 percent having ages more than or equal to 50 years but with large household size. It was also revealed that $82.5 \%$ of the respondents acquired land through inheritance while $80 \%$ had more Than 15 years of farming experience. Only $45.8 \%$ of the respondents had less than 4 hectares of land as farm size, indicating that larger percent of maize farmers in the study area operated on smallmedium scale. About $57.5 \%$ of them made use of family labour which was attributed to large household size experienced in the study area. Personal savings as source of finance was prevalent in the study area as $78.3 \%$ indicated it.

\begin{tabular}{|c|c|c|}
\hline Variable & Frequency & Percentage \\
\hline \multicolumn{3}{|l|}{ Gender } \\
\hline Female & 28 & 23.30 \\
\hline Male & 92 & 76.70 \\
\hline \multicolumn{3}{|l|}{ Marital status } \\
\hline Married & 80 & 66.70 \\
\hline Single & 4 & 3.3 \\
\hline Widow/Divorced & 36 & 30 \\
\hline \multicolumn{3}{|l|}{ Age } \\
\hline$>30$ & 4 & 3.3 \\
\hline $30-39$ & 4 & 3.3 \\
\hline $40-49$ & 17 & 14.7 \\
\hline $50-59$ & 39 & 30.7 \\
\hline 60 and above & 56 & 48 \\
\hline \multicolumn{3}{|l|}{ Primary Occupation } \\
\hline Farming & 108 & 90 \\
\hline Civil Service & 8 & 6.7 \\
\hline Artisan & 4 & 3.3 \\
\hline Trading & 17 & 9.4 \\
\hline Contractors & 20 & 11.1 \\
\hline \multicolumn{3}{|l|}{ Household size } \\
\hline $1-4$ & 4 & 3.3 \\
\hline $5-8$ & 80 & 66.7 \\
\hline $9-12$ & 20 & 16.67 \\
\hline 13 and above & 16 & 13.33 \\
\hline \multicolumn{3}{|l|}{ Farming experience } \\
\hline$>15$ & 24 & 20 \\
\hline $15-20$ & 32 & 26.67 \\
\hline 21 and above & 64 & 53.33 \\
\hline \multicolumn{3}{|l|}{ Educational level } \\
\hline No formal education & 52 & 43.3 \\
\hline Primary & 20 & 16.7 \\
\hline Secondary & 36 & 30 \\
\hline Tertiary & 12 & 10 \\
\hline \multicolumn{3}{|l|}{ Extension Contacts } \\
\hline Visit & 46 & 25.6 \\
\hline No visit & 134 & 74.4 \\
\hline \multicolumn{3}{|l|}{ Membership of Cooperative Society } \\
\hline Member & 68 & 37.8 \\
\hline Non-member & 112 & 62.2 \\
\hline \multicolumn{3}{|l|}{ Farm size (hectares) } \\
\hline$<4.00$ & 55 & 45.8 \\
\hline $4.01-8.00$ & 34 & 28.33 \\
\hline $8.01-12.00$ & 23 & 19.17 \\
\hline$>12$ & 8 & 6.67 \\
\hline \multicolumn{3}{|l|}{ Mode of land acquisition } \\
\hline Inheritance & 99 & 82.50 \\
\hline Purchase & 0 & 00 \\
\hline Lease & 15 & 12.50 \\
\hline Communal & 6 & 5 \\
\hline \multicolumn{3}{|l|}{ Source of labour } \\
\hline Family labour & 69 & 57.5 \\
\hline Hired labour & 11 & 9.2 \\
\hline Family/hired labour & 30 & 25 \\
\hline Self labour & 10 & 8.3 \\
\hline \multicolumn{3}{|l|}{ Source of finance } \\
\hline Bank & 4 & 3.3 \\
\hline Cooperative & 14 & 11.7 \\
\hline Loan/gift from friends/relative & 8 & 6.7 \\
\hline Personal savings & 94 & 78.30 \\
\hline
\end{tabular}

Table 1. Analysis of Socio-Economic Characteristics of the Respondents.

Source: Field survey, 2016. 


\subsection{Costs and Returns}

The budgetary analysis (Table 2) showed that the TVC formed the bulk $86.52 \%$ of the TC while the TFC was just $13.47 \%$. This implies that farmers who want to be cost efficient have to reduce TVC especially the cost of labour that is more than three quarter $(66.12 \%)$ of the total cost. TFC is small probably because of very low cost of land rent in the area. This is typical of core rural communities in Southwestern Nigeria where most lands are currently held by inheritance as presented in the result. The total profit of N116,590 per hectare and percentage profit of $58.63 \%$ shows that maize farming is a highly profitable venture in the area.
The cost ratio showed that a farmer that invested 1 realized $¥ 1.59$ as revenue or gained $¥ 0.59 \mathrm{k}$ on each Naira expended.

Profitability Measures

(a) Profit $=$ Total revenue - Total cost, 315,460 $\$ 198,870=\$ 116,590$

(b) Gross margin $=$ Total revenue - Total variable costs, \$315,460- $172,070=\$ 143390$

(c) Cost ratio $=\mathrm{TR} / \mathrm{TC}=\$ 315,460 / \mathrm{N} 198,870=\mathrm{N} 1.59$

(d) Gross ratio $=\mathrm{TC} / \mathrm{TR}=\mathrm{N} 198,870 / \mathrm{N} 315,460=0.63$

(e) Percent profit $=$ Profit/Total cost $\times 100 \%=$ N116,590/ $198,870 \times 100 \%=58.63 \%$.

Table 2. Budgetary Analysis.

\begin{tabular}{lll}
\hline S/N & Description Value (A) & Percentage \\
\hline Variable Costs & & \\
Cost of labour & $131,500.00$ & 66.12 \\
Cost of pesticides & $19,480.00$ & 9.80 \\
Cost of fungicides & $21,090.00$ & 10.60 \\
Total variable cost (TVC) & $172,070.00$ & 86.52 \\
Fixed Costs & & 3.62 \\
Land rent & $7,200.00$ \\
Depreciation & $19,600.00$ \\
Total fixed cost (TFC) & 15824.00 \\
Total cost (TC) & 198,870 \\
Total revenue & \\
(Income) (TR) & $315,460.00$ \\
Profit (TR - TC) & $116,590.00$ \\
\hline
\end{tabular}

Source: Field Survey, 2016.

\subsection{Productivity Analysis of Maize Farmers}

\subsubsection{Summary Statistics of Variables}

Table 3 presents the summary statistics of variables of the stochastic frontier production function for maize production. The mean output of maize harvested by farmers was $10,289.75 \mathrm{~kg}$ with a relatively high variability as shown by the standard deviation of $3931.50 \mathrm{~kg}$. The average amount of money spent on farm tools was $\$ 4414.83$ with standard deviation of 2277.46 , indicating that productivity will be very low. The average number of farm size cultivated by the farmers was 3.39 hectares and standard deviation of 1.57 indicates little or no mechanized activities. The labour used in maize production had an average number of 27 man-days and standard deviation of 15 man-days. $\$ 8,84$ was the average amount of money spent on fertilizer by the farmers with standard deviation of 21543.06 , the wide variability in fertilizer standard deviation indicates that maize production requires fertilizer for viable output.

Table 3. Summary Statistics of Variables of the Stochastic Frontier Production Function for Maize Production.

\begin{tabular}{|c|c|c|c|c|}
\hline Variables & Minimum & Maximum & Mean & Std. Deviation \\
\hline Output (kg) & 4500 & 24850 & 10289.75 & 3931.50 \\
\hline Farm Size (hectares) & 1.80 & 10.00 & 3.39 & 1.57 \\
\hline Depreciation ( & 1250 & 14500 & 4414.83 & 2277.46 \\
\hline Family labour (man-day) & 8.00 & 68.00 & 27.38 & 14.73 \\
\hline Hired labour (man-day) & 14 & 54 & 21.63 & 11.75 \\
\hline
\end{tabular}

Source: Field survey, 2016.

\subsubsection{Estimates of Stochastic Frontier Production Function Model}

Table 4 presents the estimates of the stochastic production frontier function for the maize farmers considered in the study. Estimates of the parameters of the stochastic frontier production model revealed that all the estimated coefficients of the variables of the production function were positive except that of agrochemicals. The positive coefficients of farm size, quantity of seed, family labour, hired labour, and depreciation imply that maize output increases with increase in these variables while the negative coefficient of agrochemicals implies that maize output decreases with increase in the variable. Farm size, family labour, quantity of seed used and depreciation did exert significant effects on maize output as shown by their t-ratio values. The implication of this is that increase in the level of use of these variables, will increase output of maize in the study area. 
Efficiency analysis of maize production in the area revealed that great technical inefficiency effects existed in maize production in the study area as confirmed by the gamma value of 0.674 . The gamma $(\gamma)$ ratio indicates the relative magnitude of the variance $\sigma 2$, associated with the technical inefficiency effects. Therefore, the gamma value of 0.674 implies that 67.4 percent variation in the output of maize farmers was due to differences in the technical inefficiencies of the maize farmers.

The parameter estimates from the inefficiency model included in the stochastic production frontier estimation revealed that educational level, extension access, land acquisition and farming experience had significant negative effect on technical inefficiency. This also underscores the importance of education, land acquisition, farming experience and extension access in maize production through improvement in the technical knowledge of maize farmers in Nigeria.

The hypothesis is defined thus: $\mathrm{H}_{1}: \delta 1=\delta 2=\delta 3=\delta 4=\delta 5=$ 0 , where $\delta \mathrm{i}$ is the individual explanatory coefficient (i.e. socio-economic variables of the farmers have no significant relationship on the level of maize output level). In Table 4, it was revealed that farming experience, land acquisition, extension access and access to credit were significant and as such the null hypothesis was rejected for the farming experience, land acquisition, extension access and access to credit among the other inefficiency variables of the maize farmers. Therefore, it can be concluded that not only the production function variables determine TE of maize farmers; there exists a significant inefficiency effect from four of their inefficiency variables.

Table 4. Maximum Likelihood Stochastic Function Estimates.

\begin{tabular}{|c|c|c|c|c|}
\hline Variable & Parameter & Coefficient & Standard Error & t-ratio \\
\hline Constant & $\beta_{0}$ & -0.217 & 0.145 & -0.149 \\
\hline Farm size & $\beta_{1}$ & $0.409 * * *$ & 0.143 & 6.366 \\
\hline Agrochemicals & $\beta_{2}$ & -0.459 & 0.397 & -1.156 \\
\hline Family labour & $\beta_{3}$ & $0.195 * * *$ & 0.203 & 3.924 \\
\hline Depreciation & $\beta_{4}$ & $0.241 * * *$ & 0.142 & 0.306 \\
\hline Quantity of Seed & $\beta_{5}$ & $0.383 * * *$ & 0.145 & 0.929 \\
\hline Hired labour & $\beta_{6}$ & $0.192 * * *$ & 0.677 & 0.284 \\
\hline \multicolumn{5}{|l|}{ Inefficiency factors } \\
\hline Constant & $\delta_{0}$ & 0.837 & 0.503 & 0.166 \\
\hline Age & $\delta_{1}$ & 0.472 & 0.315 & 1.498 \\
\hline Sex & $\delta_{2}$ & 0.323 & 0.503 & 0.166 \\
\hline Educational Level & $\delta_{3}$ & -0.174 & 0.156 & -0.112 \\
\hline Extension Access & $\delta_{4}$ & $0.127 * * *$ & 0.216 & 0.584 \\
\hline Farming Experience & $\delta_{5}$ & $-0.501 * * *$ & 0.821 & -0.609 \\
\hline Access to Credit & $\delta_{7}$ & $-0.197 * * *$ & 0.231 & -0.853 \\
\hline Access to Fertilizer & $\delta_{8}$ & 0.765 & 0.468 & 1.635 \\
\hline \multicolumn{5}{|l|}{ Summary of TE } \\
\hline Mean TE & 0.631 & & & \\
\hline Min. TE & 0.369 & & & \\
\hline Max. TE & 0.987 & & & \\
\hline \multicolumn{5}{|l|}{ Variance Parameters } \\
\hline Sigma Squared & $\sigma 2$ & 0.42 & 0.489 & \\
\hline Gamma & $\gamma$ & 0.246 & 0.172 & \\
\hline Log likelihood function & & -0.147 & & \\
\hline
\end{tabular}

*** $\mathrm{P}<0.01 ; * * \mathrm{P}<0.05$ Source: Field survey, 2016.

\subsubsection{Return to Scale Analysis}

The return to scale (RTS) analysis which served as a measure of resource productivity is given in Table 5 . The RTS parameter (0.931) was obtained from the summation of the coefficients of the estimated inputs (elasticities) which indicates that cocoa production in the study area was in the Stage II of the production surface meaning that these variables were efficiently utilized in course of maize production, and thus the production is efficient. The RTS reported in this study was very close to the value of 0.84 reported by [17] in a study on examination of technical, economic and allocative efficiency of small farmers: the case study of Osun State, Nigeria.
Table 5. Elasticities and Return to Scale (RTS) Analyzes of Production Function.

\begin{tabular}{ll}
\hline Variables & Elasticities \\
\hline Farm size & 0.409 \\
Family labour & 0.195 \\
Hired labour & 0.192 \\
Agrochemical & -0.459 \\
Depreciation & 0.241 \\
Quantity of seed & 0.353 \\
Return to Scale & 0.931 \\
\hline
\end{tabular}

Source: Field survey, 2016.

\subsubsection{Technical Efficiency Analysis}

The TE ranged between 0.298 and 0.965 with mean 
technical efficiency of 0.643 . The decile range distribution of the TE showed that about only $23.33 \%$ of the maize farmers had technical efficiencies of 0.8 and above. The remaining $76.67 \%$ of the farmers had TE less than 0.8 . The study revealed that the sampled farmers were relatively very technically inefficient, meaning that larger percent of the farmers obtained minimum output from a given set of inputs with an increased level of resources wastage.

Table 6. Frequency Distribution of Technical Efficiency Indices.

\begin{tabular}{lll}
\hline Technical Efficiency Range & Frequency & Percentage \\
\hline$\leq 0.4$ & 6 & 4.67 \\
$0.41-0.60$ & 51 & 42.67 \\
$0.61-0.80$ & 35 & 29.33 \\
$0.80-1.00$ & 28 & 23.33 \\
Total & 120 & 100 \\
\hline
\end{tabular}

Source: Field survey, 2016.

\subsection{Problems of Maize Production of the Respondents}

The problems of maize production in the study area are stated in multiple responses form in Table 7 below where $96.7 \%$ of the respondents identified labour inadequacy as their problem. Also, 83.3\%, 83.3\%, 96.7\%, 70.0\%, 86.7\% and $93.3 \%$ indicated low produce price, high cost of fertilizer, inadequate credit facility, theft, pest-disease and high cost of transportation as their problems respectively.

Table 7. Distribution of the Respondents by Challenges to Maize Production.

\begin{tabular}{lll}
\hline Challenges & Frequency & Percentage \\
\hline Pests & 116 & 96.70 \\
Diseases & 100 & 83.30 \\
Theft & 41 & 34.20 \\
Inadequate rainfall & 116 & 96.70 \\
Inadequate credit facilities & 85 & 72.00 \\
Inadequate extension visits & 104 & 86.70 \\
Poor roads & 112 & 93.30 \\
\hline
\end{tabular}

Multiple responses Source: Field Survey, 2016.

\section{Conclusion and Recommendations}

Maize production is highly profitable and leaves farmers with high returns on their investments. The farmers are highly efficient in its production at the present level of technology available to them. The level of technical efficiency in maize production in Ekiti State ranged from $29.8 \%$ to $96.5 \%$ with a mean of $64.3 \%$. This means that there are substantial opportunities to increase productivity and income through more efficient utilization of productive resources. Farmers have to cut down the variable costs in order for them to increase their profit. Since the bulk of the variable cost is incurred on labour, attempts at reducing this cost will lead to greater gross margins and hence the profitability of the enterprise.

It is therefore suggested that effort should be geared towards increasing the technical manpower of farmers, land redistribution policy that will increase the farm size of farmers in order to boost maize production should be encouraged; and in order to increase farmers' profit, variable costs have to be cut down, since the bulk of the variable cost is incurred on labour, which would lead to greater gross margins and hence the profitability of the enterprise.

\section{References}

[1] Food and Agriculture Organization (2003). FAOSTAT http://faosata.fao.org/ default.htmm

[2] World Bank Washington, D.C, Mimeo 2003. World Development Indicators, 2003. Washington, D. C. CD-ROM.

[3] Central Bank of Nigeria. (2003): Annual Report and Statement of Accounts. Abuja, Nigeria: CBN Publication.

[4] International Fund for Agricultural Development (2002). Annual Report Lusaka.

[5] Kuriuki D. K, Ritho C. N and Muneik.2008. Analysis of the Effect of Land Tenure on Technical Efficiency in Smallholder Crop production in Kenya. Conference on International Research on Food Security, Natural Resource Management and Rural Development. Tropentag.

[6] FMARD. (2001). Agricultural Policy Thrust. Abuja: Federal Ministry of Agriculture and Rural Development. Food and Agriculture Organization (2003): FAOSTAT http://faosata.fao.org/default.htmm International Fund for Agricultural Development (2002): Annual Report. Lusaka.

[7] Fasasi, O. S. (2008). Functional and Visco-Elastic Properties of Traditional Processed Quality Protein Maize (QPM) Seed Flour Proceedings of the Fourth Annual Conference of the School of Agriculture and Agricultural Technology, Akure, Nigeria: 2224.

[8] Osundahunsi, O. F. and Aworh, O. C. (2000): Moisture Equilibra of Tempe-Fortified Maize -Based Complementary Foods. Applied Tropical Agriculture 5: 4147.

[9] Ristanovic, D. (2001): Maize In: R. H Raemaekers (Editor) Crop Production in Tropical Africa. Goekint Graphics nv. Belgium. pp 23-45.

[10] Oladeebo, J. O. (2004): Resource-Use Efficiency of Small and Large Scale Farmer in South Western Nigeria: Implication of Food Security. International Journal of Food and Agricultural Research. Vol. 1, No. 12, Pp 227-235.

[11] Awoke M. U. and C. Okorji (2004). The Determination and Analysis of Constraints in Resource Use Efficiency in Multiple Cropping Systems by Small- holder Farmers in Ebonyi State, Nigeria Africa Development. 2004; Vol. xxix, No. 3, Pp. 58-69.

[12] Likita, T. (2005): Technical Efficiency in Arable Crop Production in Kebbi State Nigeria. Journal of Agriculture and Food Science. Vol. 3, No. 2, Pp. 165-174.

[13] Ajayi S. T (2005). Cattle Productivity in Nigeria; Problems and Prospects". A paper presented at the National Workshop on Improving Productivity in Cattle farming in Nigeria. Organized by The National Productivity Centre on $21^{\text {st }} 22^{\text {nd }}$ September 2005 in Kaduna State, Kaduna, Nigeria. 
[14] Saliu O. J., S. O. Ukwuteno and D. O. Ekpa (2006): Constrains in the Adoption of Improved Oil Palm Technology among Small Scale Farmers in Dekina Local Government Area of Kogi State. Journal of Scientific and Industrial Studies 4(3): 29-32.

[15] Battese, G. E. and Coelli, T. J. (1996): “A Model for Technical Inefficiency Effects in a Stochastic Frontier Production Function for Panel Delta”. Empirical Economics 20: 325- 335.
[16] Ajibefun, I. A. and Daramola, A (2002): Inefficiency of production of farmers under the National Directorate of in Ondo State, Nigeria. Applied Economic Letters, Routledge, 6. 111-114.

[17] Ogundari, K. and S. Ojo (2007). Economic Efficiency of small scale food crop production in Nigeria: A stochastic frontier approach, Journal of Social Sciences, vol 14, no. 2, pp 123 130. 